\title{
P01-001 - Musculoskeletal sonography in FMF patients
}

\author{
O Karadag ${ }^{*}$, S Yilmaz, V Yazisiz, M Cinar, H Erdem, S Pay, A Dinc \\ From 7th Congress of International Society of Systemic Auto-Inflammatory Diseases (ISSAID) \\ Lausanne, Switerland. 22-26 May 2013
}

\section{Introduction}

Familial Mediterranean fever (FMF) is an autoinflammatory disorder characterized by recurrent febrile polyserositis and musculoskeletal findings. Chronic arthritis and/or accompanying seronegative spondyloarthropathy have been reported in FMF. But little is known about musculoskeletal changes during attack free period.

\section{Objectives}

This study is aimed to investigate the musculoskeletal sonographic changes during attack free period.

\section{Methods}

Totally 29 consecutive FMF male patients at attack free period and 17 male controls were included into the study. Physical examination (PE) was performed to detect Achilles enthesitis and/or retrocalcaneal bursitis, knee arthritis. US of the lower extremity were performed bilaterally. Grey-scale (GS) and power Doppler (PD) scores on a $0-2$ semi-quantitative scale $(0$ : no, 1 : mild, 2: moderate, 3: marked).

\section{Results}

Mean ages of patients and controls were $24.3 \pm 4.9,25.8$ \pm 5.5 years $(\mathrm{p}=0.338)$. Fourteen $(48.2 \%)$ of FMF patients had reported arthralgia and/or arthritis during attacks. In 7 of 15 patients who had not reported joint problems, a sonographic pathology was found (4 of them was mild effusion at knee and 3 of them was retrocalcaneal bursitis and medial tenosynovitis. No PDS was found in knee or ankle joint. But there was no pathology in controls.

\section{Conclusion}

Even though none of the FMF patients had chronic arthritis, an increased rate of mild effusion and

Division of Rheumatology, Gulhane School of Medicine, Ankara, Turkey tenosynovitis was found. This finding might reflect an increased rate of musculoskeletal finding compared to healthy controls.

\section{Disclosure of interest}

None declared.

Published: 8 November 2013

doi:10.1186/1546-0096-11-S1-A5

Cite this article as: Karadag et al:: P01-001 - Musculoskeletal

sonography in FMF patients. Pediatric Rheumatology 2013 11(Suppl 1):A5.
Submit your next manuscript to BioMed Central and take full advantage of:

- Convenient online submission

- Thorough peer review

- No space constraints or color figure charges

- Immediate publication on acceptance

- Inclusion in PubMed, CAS, Scopus and Google Scholar

- Research which is freely available for redistribution
() Bïomed Central

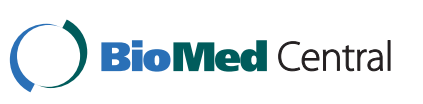
Attribution License (http://creativecommons.org/licenses/by/2.0), which permits unrestricted use, distribution, and reproduction in any medium, provided the original work is properly cited. 